\title{
A method for the generation of YAC transgenic mice by pronuclear microinjection
}

\author{
Andreas Schedl ${ }^{+}$, Zoia Larin ${ }^{1 \S}$, Llúis Montoliu, Edda Thies, Gavin Kelsey, Hans Lehrach ${ }^{1}$ and \\ Günther Schütz* \\ Division Molecular Biology of the Cell I, German Cancer Research Center, Im Neuenheimer Feld \\ 280, 69120 Heidelberg, Germany and ${ }^{1}$ Imperial Cancer Research Fund, Genome Analysis \\ Laboratory, Lincoln's Inn Fields, London WC2A 3PX, UK
}

Received June 29, 1993; Revised and Accepted September 7, 1993

\begin{abstract}
Yeast artificial chromosomes (YACs) represent the latest generation of vectors which have the great advantage of large insert size. The introduction of YACs into mammalian cells and organisms has become an important goal, since it offers the potential to study the control of large and complex transcription units and identify genes by complementation. Microinjection into the nucleus is the most direct and efficient way of delivering YAC DNA into cells, but requires the purification of the YAC from the remaining yeast chromosomes. Here we describe a detailed method for the isolation of pure, intact and highly concentrated YAC DNA. As a model system the murine tyrosinase gene was chosen and four YACs covering this locus were isolated. Introduction by homologous recombination in yeast of sequences permitting YAC amplification greatly facilitated the isolation of YAC DNA at high concentrations. YAC DNA stabilized in a salt and polyamine containing buffer did not compromise the survival of microinjected oocytes and was suitable for the generation of transgenic mice. Applications and benefits of this technique will be discussed.
\end{abstract}

\section{INTRODUCTION}

Yeast artificial chromosomes (YACs) (1) have proven to be a powerful tool in cloning large fragments of DNA and in genome analysis. Unique amongst cloning vectors they offer the possibility of cloning and stably maintaining in excess of $1000 \mathrm{~kb}$ of DNA in the yeast host Saccharomyces cerevisiae. Therefore, they can be used to close the existing gap between genetic and physical maps and to clone complex transcriptional units and gene clusters on single fragments of DNA. Furthermore, YACs are easily manipulated and modified owing to the highly active recombination system in yeast in which homologous events greatly predominate.
Given these potentials, the introduction of YACs into mammalian cells and the germline of the mouse has been a major goal. By overcoming the size constraints imposed by other vectors, YACs will allow the function and regulation of genes and gene clusters to be studied in conditions closely approaching their natural context. YACs have been introduced into mammalian cell lines, including embryonic stem (ES) cells, by spheroblast fusion (2-5), lipofection (6), calcium phosphate coprecipitation (7), and electroporation (8). In these cases, however, the entire yeast genome was introduced in addition to the YAC DNA. Although mice have been produced from ES cells containing the entire yeast genome without apparent adverse effects (5), the vast amount of additional genetic material is undesirable and a potential source of insertional mutagenesis. Isolated YAC DNA has been introduced into somatic cells (9) and ES cells $(10,11)$ by lipofection, but the number of clones with integrated YAC DNA was relatively low. The manipulated ES cells were able to contribute to the germline of mice.

The most direct and efficient way to deliver DNA into cells is microinjection into the nucleus, and YAC DNA has been introduced into cultured cells (12) and the germline of mice $(13,14)$ by this means. For the successful application of this technique to the generation of transgenic mice, the DNA must be intact, sufficiently concentrated to ensure a high frequency of integration and pure enough to allow survival of the oocytes. In addition, the DNA should be stabilized to prevent shearing of the large molecules during purification and passage through the microinjection needle. The large size, linearity and single copy nature of YACs make preparation of clean, intact and concentrated DNA difficult. This difficulty could be overcome with an amplifiable YAC vector (15) based on a conditional centromere (16), which allows up to 25 fold amplification of the YAC in yeast. After such amplification, YAC DNA can account for as much as $50 \%$ of the entire yeast DNA. Unfortunately, the YAC libraries presently available have not been constructed with this type of amplifiable vector. Here we describe the modification of a YAC covering the tyrosinase locus to allow

\footnotetext{
* To whom correspondence should be addressed
}

Present addresses: ${ }^{+}$MRC Human Genetics Unit, Western General Hospital, Crewe Road, Edinburgh EH4 2 XU and ${ }^{8} \mathrm{CRC}$ Chromosome Molecular Biology Group, Department of Biochemistry, University of Oxford, South Parks Road, Oxford OX1 3QU, UK 
its amplification and a protocol for the isolation of highly concentrated, pure and stabilized YAC DNA, which we have been able to use for the generation of transgenic mice (14).

\section{MATERIALS AND METHODS}

\section{Isolation and characterization of YACs}

The tyrosinase cDNA clone pmcTyr 102 (17) was used to screen a YAC library of C3H mouse DNA (18) by colony filter hybridization. Four independent YACs were isolated and designated Tyr 1 to Tyr4. In addition to pmcTyr 102, four mouse genomic probes (Figure 1) were used to characterize the YACs: Tyr14.E6 is a $3.6 \mathrm{~kb}$ EcoRI fragment from $\lambda \mathrm{gTYR} 14$ (17); JLE1.7, ILE4.8 and JLE1.2 have been described elsewhere (19). Radioactively labelled mouse DNA was used to detect all mouse DNA containing restriction fragments of the YACs. Probes specific for the left and right YAC vector arm were generated by digestion of pBR322 with $E c o$ RI and $P v u I I$; the $2.3 \mathrm{~kb}$ and $2.0 \mathrm{~kb}$ fragments were used for the long and short arm, respectively. Agarose plugs of YAC DNA for mapping were prepared essentially as described (20) and contained $1 \times 10^{8}$ cells per $80 \mu \mathrm{l}$ plug. Methods for digestion, pulsed field gel electrophoresis (PFGE), blotting, radioactive probe synthesis and hybridization have previously been described (19)

\section{Media and yeast transformation}

YAC Tyr 1 was modified by spheroblast transformation (essentially as described in 21) of the corresponding yeast strain with $5 \mu \mathrm{g}$ of BamHI linearized pFRAT3' (Figure 2). pFRAT3' was constructed by cloning a $5 \mathrm{~kb} E c o \mathrm{RI} / \mathrm{BamHI}$ fragment from $\lambda$ gTYR4 (17) which contains exon 5 of the tyrosinase gene into the $10 \mathrm{~kb}$ fragment of EcoRI/BamHI digested Y-RC16 (13). Transformants were selected on synthetic medium (lacking uracil) containing $0.8 \mathrm{mg} / \mathrm{ml}$ thymidine, $50 \mu \mathrm{g} / \mathrm{ml}$ methotrexate, $2 \mathrm{mg} / \mathrm{ml}$ sulphanilamide, $2 \%$ agar and $1 \mathrm{M}$ sorbitol. The appropriately modified YAC was called YRT2. Transformation of YRT2 into S.cerevisiae strain CGY2516 (MATa GAL + ura3-52 trpl- $\triangle 63$ leu2- $\Delta 1$ lys2- $\Delta 202$ his3- $\Delta 200$; ATCC \# 74013) was carried out after isolation of YAC DNA from a preparative pulsed field electrophoresis gel (running conditions as below) followed by agarase (Gelase, Epicentre) digestion. Transformants were selected on synthetic medium (22) lacking uracil. Amplification of the YAC was performed as described previously $(13,15)$.

\section{Isolation of YAC DNA and microinjection into mouse oocytes}

$200 \mathrm{ml}$ of selective medium lacking uracil were inoculated with $200 \mu \mathrm{l}$ of amplified YRT2 yeast culture (grown as described in refs. 13,15) and shaken for two days at $30^{\circ} \mathrm{C}$. Cells were collected by centrifugation at $3000 \mathrm{rpm}$ for $5 \mathrm{~min}$ (Sorvall RT $6000 \mathrm{~B}$ ), washed once in double destilled water and once in SCE (1M sorbitol, 0.1M Na 3 citrate, 10mM EDTA, pH7.0) and collected in a single tube. After careful removal of the supematant a few drops of SCE were added to the pellet sufficient to take up the cells in a thick suspension. The same volume of preheated $\left(50^{\circ} \mathrm{C}\right) 1 \%$ low melting point (LMP) agarose (BRL Ultrapure) dissolved in SCE containing $20 \mathrm{mg} / \mathrm{ml}$ Novozyme 234 (NovoBiolabs) was added and the mixture quickly dispensed into Pharmacia plug formers $(80 \mu \mathrm{l} / \mathrm{plug})$ sitting on ice. After $10 \mathrm{~min}$ the plugs were transfered to SCE supplemented with $10 \mathrm{mM}$ DTT, incubated for $3 \mathrm{~h}$ at $37^{\circ} \mathrm{C}$ and then to a $1 \%$ lithium dodecyl sulphate $/ 100 \mathrm{mM}$ EDTA solution for $16 \mathrm{~h}$ at $50^{\circ} \mathrm{C}$. After removing the detergent by several washings in TE $(10 \mathrm{mM}$ Tris: $\mathrm{HCl}, 1 \mathrm{mM}$
EDTA, pH8.0) plugs were stored at $4^{\circ} \mathrm{C}$ in $0.5 \mathrm{M}$ EDTA pH8.0 until use.

For purification of YAC DNA, plugs equilibrated in TE were loaded next to one another in a $4 \mathrm{~cm}$ slot of a $20 \times 20 \mathrm{~cm} 1 \%$ LMP agarose (Seaplaque, FMC) $0.25 \times \mathrm{TAE}$ gel $(\mathrm{TAE}=40 \mathrm{mM}$ Tris:acetate, $1 \mathrm{mM}$ EDTA). The plugs were positioned vertically to occupy the height of the gel. PFGE running conditions optimized for the $250 \mathrm{~kb}$ YAC were $250 \mathrm{~V}$ for $10 \mathrm{~h}$ with a switch interval of $9 \mathrm{~s}$, followed by $6 \mathrm{~h}$ with a $15 \mathrm{~s}$ switch. After staining marker lanes on either side with ethidium bromide, a gel slice containing YAC DNA was excised from the preparative lane, and yeast chromosome DNA containing slices above and below the YAC band were removed to serve as marker lanes for the second gel run. The gel slices were equilibrated in $1 \times$ TAE, positioned on a minigel tray with the YAC slice in the middle and a 4\% LMP agarose (Nusieve, FMC) $1 \times \mathrm{TAE}$ gel cast around them. A second gel run $(3-5 \mathrm{~h}, 4 \mathrm{~V} / \mathrm{cm})$ was performed, with buffer circulation, at a $90^{\circ}$ angle to the PFGE run. The two marker lanes were stained to localize the DNA, and the concentrated material was excised from the corresponding position of the YAC DNA lane. The gel slice was equilibrated in $1 \times \mathrm{TAE}, 100 \mathrm{mM} \mathrm{NaCl}, 30 \mu \mathrm{M}$ spermine, $70 \mu \mathrm{M}$ spermidine, melted at $68^{\circ} \mathrm{C}$ for $10 \mathrm{~min}$, and digested with $4 \mathrm{U}$ Gelase (Epicentre) per $100 \mathrm{mg}$ of gel slice for $2 \mathrm{~h}$. The resulting DNA solution was dialysed for $2 \mathrm{~h}$ on a floating dialysis membrane (Millipore, pore size $0.05 \mu \mathrm{m}$ ) against microinjection buffer: $10 \mathrm{mM}$ Tris: $\mathrm{HCl}, \mathrm{pH} 7.5,0.1 \mathrm{mM}$ EDTA, $100 \mathrm{mM} \mathrm{NaCl}, 30 \mu \mathrm{M}$ spermine, $70 \mu \mathrm{M}$ spermidine. The concentration of purified DNA was estimated on a $0.8 \%$ agarose minigel using $\lambda$ DNA of known concentration as a standard.

DNA was microinjected into the pronuclei of NMRI/Han fertilized oocytes following standard techniques (23). Oocytes surviving manipulation were transferred to NMRI/Han foster mothers. Transgenic mice were identified on Southern blots of HindIII digested tail biopsy DNA hybridized with randomly primed 4.5 and 5.4kb HindIII fragments of Y-RC16 (13).

\section{RESULTS AND DISCUSSION}

Isolation and characterization of YACs covering the mouse tyrosinase locus

The mouse tyrosinase gene was chosen to develop procedures for the creation of transgenic mice with YAC DNA because of the large size of the gene $(80 \mathrm{~kb}$, reference 17$)$, and because tyrosinase expression determines an obvious phenotype in mice $(14,24-26)$. Four YACs (Tyr1 to Tyr4) containing the tyrosinase gene were isolated from a YAC library of C3H DNA (18) after screening with a full length tyrosinase cDNA probe (17). The YACs were characterized by hybridization ofSmal digests with mouse DNA, the tyrosinase cDNA and four genomic probes spanning the tyrosinase locus (Figure 1 and data not shown). In addition, probes for the vector arms were used to identify fragments at the ends of the YACs. The restricition maps of YACs Tyrl and Tyr2 were found to be in good agreement with a long-range map of SmaI sites established around the mouse tyrosinase gene ( $c^{\text {ch }}$ allele, G.K., unpublished results). The only significant discrepancy between the YACs and the long range map concerned the Smal fragments at the $5^{\prime}$ end of the tyrosinase gene: $75 \mathrm{~kb}$ on the YACs, $60 \mathrm{~kb}$ detected by Tyr 14:E6 in $c^{c h} / c^{c h}$ DNA, and $58 \mathrm{~kb}$ on the $c^{\text {ch }}$ allele cloned in $\lambda$ libraries. This difference might indicate an insertion in the C3H DNA carried on the YACs, and might account for an EcoRI site polymorphism 

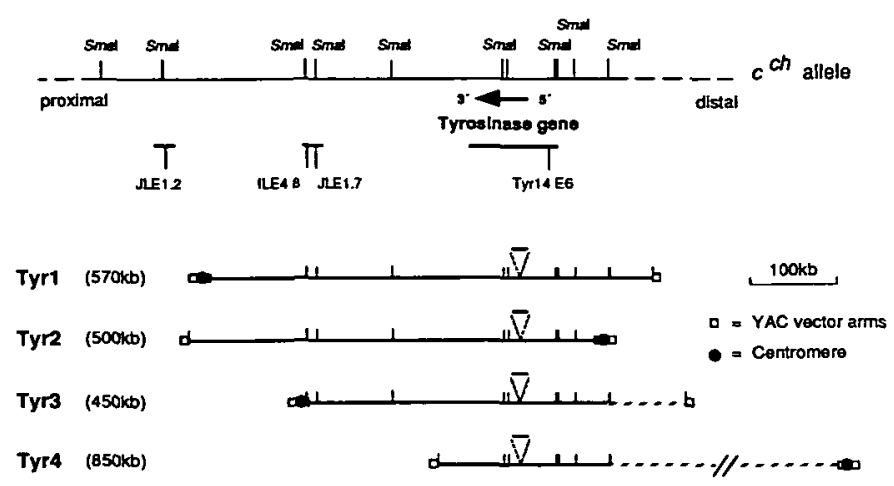

Figure 1. Characterization of YACs encompassing the tyrosinase locus. The upper line represents a physical map of SmaI sites around the mouse tyrosinase $(c)$ locus (the $c^{c h}$ allele, details avaliable on request). Proximal and distal indicate orientation with respect to the centromere of mouse chromosome 7 . Regions cloned in $\lambda$ phages $(11,19,34)$ are depicted as thick lines below the chromosome. The position of probes used to analyse of the tyrosinase gene YACs are indicated. Below, the physical maps of the four YACs (Tyr1, Tyr2, Tyr3 and Tyr4) isolated with the tyrosinase CDNA are shown. YAC vector sequences are given as open boxes. Circles represent the centromeres on the long vector arms. Broken lines are regions of the YACs which have not been mapped in detail and might correspond to coligations or rearrangements of the inserts. The bar above the $55 \mathrm{~kb}$ Smal fragment within the tyrosinase region of the YACs indicates a restriction fragment length variant between the $c h$ and the $\mathrm{C} 3 \mathrm{H}$ allele.

identified previously (14). Tyr3 was suspected to have undergone a rearrangement at its distal end, since YACs of 500 and $450 \mathrm{~kb}$ were detected by hybridization in the original isolate, and the YAC long arm probe detected two fragments in SmaI digests. Tyr4 contained few Smal fragments in common with the other YACs, which implied that it extended the furthest distally. However, the lack of information of SmaI sites distal to the tyrosinase gene precluded its further characterization, and analysis with other enzymes suggested that Tyr 4 might be a chimaeric clone (A.S., unpublished results). All four YACs cover the entire tyrosinase gene as judged by hybridization of the cDNA probe to $75 \mathrm{~kb}$ and $130 \mathrm{~kb}$ Smal fragments containing the $5^{\prime}$ and $3^{\prime}$ halves of the tyrosinase gene, respectively, with the exception that in Tyr4 the $130 \mathrm{~kb}$ SmaI fragment was replaced by a $70 \mathrm{~kb}$ fragment at one end of the YAC (Figure 1).

The tyrosinase YACs map to the centre of the region on chromosome 7 defined by a series of radiation induced deletions that comprise the albino-deletion complex. Many albino deletions have recessive lethal phenotypes and genetic complementation tests have identified at least six loci which are required for normal mouse development (reviewed in 27). In addition to the present studies, the tyrosinase YACs will provide a useful resource for the positional cloning approaches which have been initiated for several of these loci (28).

\section{Modification of YAC Tyr1 and isolation of YAC DNA}

To obtain higher yields of YACs for purification of DNA, we introduced an amplification system (15) into Tyrl. The vector arm containing the centromere maps $3^{\prime}$ to the tyrosinase gene in Tyr1. A fragmentation vector, pFRAT3' (Figure 2), was designed which consists of $5 \mathrm{~kb}$ sequences homologous to the $3^{\prime}$ end of the tyrosinase gene and the centromere containing arm of Y-RC16, an amplifiable YAC vector (13). In addition to exchanging the-centromere arm, this fragmentation strategy results in the removal of $320 \mathrm{~kb}$ proximal to the tyrosinase gene,

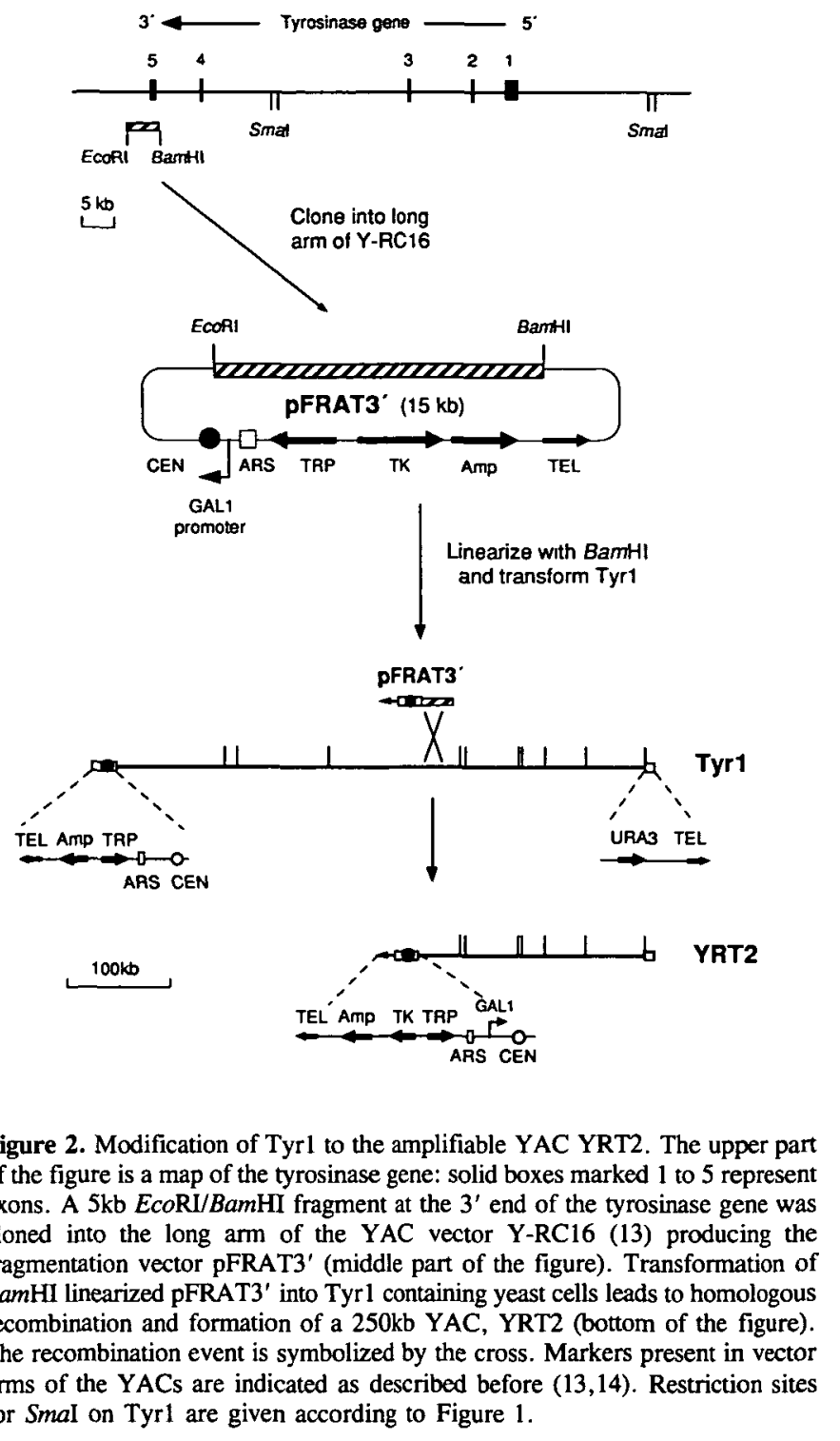

reducing the YAC from 570 to $250 \mathrm{~kb}$, but leaves unaltered the $155 \mathrm{~kb} 5^{\prime}$ to the gene, which might contain sequences important for its full level expression (Figure 2). $5 \mu \mathrm{g} \mathrm{BamHI} \mathrm{linearized}$ pFRAT3' DNA was transformed into yeast carrying Tyr 1 and recombinant clones were selected for the presence of the thymidine kinase gene. YAC clones resulting from the desired recombination event were identified by PFGE analysis of undigested yeast DNA: 7 out of 30 clones showed a new chromosomal band of the expected size of $250 \mathrm{~kb}$. The relatively high background of clones not carrying a fragmented YAC could be explained by recombination of the Trpl genes present on Tyrl and pFRAT3' or by circularization of the plasmid pFRAT3', the latter having been observed in a high percentage of unrecombined clones (data not shown).

Figure 3A shows the PFGE analysis of undigested DNA of Tyr1 and a recombinant clone, YRT2. Running conditions have been optimized for the separation of fragments around $250 \mathrm{~kb}$. Whilst the $570 \mathrm{~kb}$ band corresponding to Tyr 1 migrates just below the limited mobility DNA (L.M.D.), a band of $250 \mathrm{~kb}$ can be readily detected in YRT2 DNA. Hybridization with a probe specific for tyrosinase (Figure 3B) detects both YAC DNAs, 
A

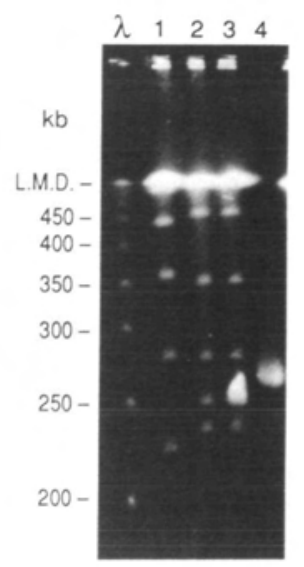

B

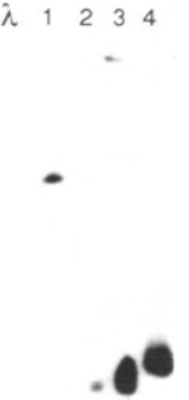

Figure 3. PFGE analysis of YAC DNA. A) DNAs (from $1 \times 10^{8}$ cells embedded in agarose plugs) from yeast strains containing Tyr1 (lane 1), YRT2 (lane 2) and YRT2 after amplification (lane 3), as well as approximately $200 \mathrm{ng}$ of purified YRT2 YAC DNA (lane 4) were separated by PFGE. The 570kb YAC Tyr1 migrates just below the DNA with limiting mobility (L.M.D.). The modified YAC, YRT2, can be seen as a band migrating between the two smallest yeast chromosomes I and VI. B) Autoradiogram of the corresponding Southern blot hybridized with a tyrosinase cDNA (pmcTyr 102). Amplification of the YAC is approximately 25 fold as determined be comparing the hybridization signals of lanes 2 and 3 (Phosphoimager, Molecular Dynamics). No degradation of the isolated YRT2 is visible (lane 4).

indicating that the smaller is a bona fide fragmentation product containing the tyrosinase gene. The structure of YRT2 was verified by restriction enzyme and hybridization analysis (data not shown).

Amplification of YACs is achieved by growth in galactose containing medium, which leads to induction of the galactose promoter and, consequently, transcription through the centromere. Amplification in the strain AB1380 has been described (29). However, we were unable to grow YRT2 and our $\mathrm{AB} 1380$ strain on galactose, which suggests that the YAC library (18) was constructed using a different isolate of AB1380. Therefore, YRT2 was transformed into the well defined Gal+ strain CGY2516 (ATCC \# 74013), a strain which has previously been used for amplification $(13,15)$. A 25 fold amplification of YRT2 was observed, as determined by comparison of the hybridization signals of a tyrosinase specific probe to DNA prepared from an equivalent number of cells before and after amplification (Figure 3B, lanes 2 and 3).

To obtain pure and highly concentrated YAC DNA suitable for microinjection, a simple two step gel purification procedure was devised (for details see material and methods). Firstly, the YAC was separated from the endogenous yeast chromosomes on a preparative pulsed field gel. A second gel run into 4\% LMP agarose was performed to increase the DNA concentration within the gel slice up to four fold. The agarose slice was equilibrated in a buffer containing polyamines with $\mathrm{NaCl}$ (Table I), in order to stabilize the YAC DNA $(18,30)$. DNA was liberated by digestion with agarase and purified by dialysis against a buffer containing $\mathrm{NaCl}$ and/or polyamines. The concentration of DNA routinely recovered by this procedure was conservatively estimated to be between 4 and $20 \mathrm{ng} / \mathrm{ml}$ and, therefore, clearly represents an improvement on other methods $(9-12)$.

Before microinjection, an aliquot of the DNA preparation was checked for integrity by PFGE analysis. The isolated DNA was
Table I. Generation of transgenic mice with YRT2 YAC DNA

\begin{tabular}{llllll}
\hline YAC DNA preparation & 1 & 2 & 3 & 4 & 5 \\
\hline Buffer composition $^{8}$ & $\mathrm{P}$ & $\mathrm{P}$ & $\mathrm{P}$ & $\mathrm{P} / \mathrm{Na}$ & $\mathrm{P} / \mathrm{Na}$ \\
DNA concentration $(\mathrm{ng} / \mu \mathrm{l})^{*}$ & 0.5 & 1 & $2-3$ & 5 & 5 \\
Oocytes microinjected $^{\text {Oocytes transferred }}$ & 257 & 256 & 340 & 214 & 425 \\
Successful pregnancies & 168 & 138 & 237 & 93 & 300 \\
(Oocytes involved) $^{\#}$ & 3 & 3 & 4 & 2 & 5 \\
Newborns & $(97)$ & $(65)$ & $(117)$ & $(66)$ & $(174)$ \\
DNA-positive transgenics & $\mathrm{K} 42$ & 19 & 26 & 8 & 16 \\
Pigmented transgenics & 1 & 2 & 0 & 2 & 3 \\
Both vector arms present & 0 & 1 & 0 & 2 & 3 \\
\hline
\end{tabular}

${ }^{8} \mathrm{P}=10 \mathrm{mM}$ Tris: $\mathrm{HCl}$ ph7.5, $0.1 \mathrm{mM}$ EDTA, $30 \mu \mathrm{M}$ spermine, $70 \mu \mathrm{M}$ spermidine $\mathrm{P} / \mathrm{Na}=\mathrm{P}+100 \mathrm{mM} \mathrm{NaCl}$

* Initial DNA concentration (see text)

\# The number of oocytes transferred to foster mothers which became pregnant

free of contamination with endogenous yeast chromosomes (Figure 3A, lane 4). Moreover, no sign of degradation could be detected, either upon ethidium bromide staining or after hybridization with a tyrosinase specific probe (Figure 3B, lane 4). Although isolation of DNA from single copy YACs is possible (12; A.S., unpublished results), DNA solutions obtained from yeast after amplification are several times more concentrated. Furthermore, preparations from unamplified YACs are more highly contaminated with endogenous yeast chromosomes and smaller, degraded DNA. These contaminants are likely to result from DNA being trapped and only slowly released from high density plugs which, therefore, comigrates with the YAC band. Recently, a method was described in which isolated YAC DNA was concentrated by centrifugation in filter units (12). Our previous trials with similar methods proved unsatisfactory, however, which might be due to differences in the purification protocols or buffers employed.

\section{Microinjection of YAC DNA into fertilized mouse oocytes}

Table I summarizes microinjection experiments performed with five independent DNA preparations. In experiments with preparations 1 to 3 , which were dialysed against a microinjection buffer lacking $\mathrm{NaCl}$, very few transgenic mice were obtained. The combination of low ionic strength and polyamines was suspected to lead to precipitation of the DNA during storage. Indeed, small particles were observed passing through the microinjection needle with these preparations. This suspicion was confirmed in tests in which $\lambda$ DNA in the presence of varying concentrations of $\mathrm{NaCl}$ and polyamines was subject to centrifugation (data not shown). Similar to results shown in ref. 12 , we found that DNA was precipitated by centrifugation in solutions containing as little as $100 \mu \mathrm{M}$ polyamines, unless $\mathrm{NaCl}$ was present at $>50 \mathrm{mM}$. Therefore, a microinjection buffer was chosen which contained $30 \mu \mathrm{M}$ spermine, $70 \mu \mathrm{M}$ spermidine and $100 \mathrm{mM} \mathrm{NaCl}$ in $10 \mathrm{mM}$ Tris: $\mathrm{HCl}, 0.1 \mathrm{mM}$ EDTA (pH7.5), in which DNA remained in solution for long periods without degradation. A much higher frequency of transgenic mice amongst live born mice was obtained with DNA microinjected in this buffer (Table I).

NMRI fertilized oocytes were microinjected and kept at $37^{\circ} \mathrm{C}$ in a $\mathrm{CO}_{2}$ incubator for periods between a few hours and overnight. The survival of oocytes at this stage $(50-75 \%)$ was comparable to that obtained with conventional DNA preparations (DNA at $4 \mathrm{ng} / \mathrm{ml}$ in $10 \mathrm{mM}$ Tris, pH7.5, 0.1mM EDTA; L.M., unpublished results). Of the oocytes microinjected with the DNA preparations in the optimized microinjection buffer (4 and 5), 
393 were transferred to 12 pseudopregnant NMRI females. Seven of these females, which had received a total of 240 oocytes, gave birth to 24 mice, of which $5(21 \%)$ were identified as transgenic by pigmentation and DNA analysis (Table $\mathrm{I}$ ). This frequency is comparable to the efficiency of transgenesis with conventional constructs (31). The number of pups obtained from the oocytes which had received YAC DNA in our optimized microinjection buffer (batches 4 and 5) was somewhat lower than expected (24 pups from 240 oocytes). However, this was compensated by the high frequency of transgenic offspring (5 out of 24). An explanation for this slight reduction could be the relatively high DNA concentrations of these preparations (estimated to be $5 \mathrm{ng} / \mathrm{ml}$ ), since DNA solutions greater than $5 \mathrm{ng} / \mathrm{ml}$ have been shown to reduce the overall efficiency of transgenesis (31).

The ability to prepare pure YAC DNA at high concentration should benefit other methods, such as the lipofection of YAC DNA into ES cells $(10,11)$ and the microinjection of somatic cells (12). The recovery of ES clones with integrated YAC DNA has been plagued by problems of low efficiency, which might be due, in part, to the limiting amounts of YAC DNA used. In addition, the majority of ES and somatic cells into which YAC DNA has been lipofected were shown to contain incomplete copies of the YAC DNA (10-12). This implies that lipofection may suffer from a size limitation, and suggests that microinjection will be the method of choice for larger molecules $(12,14)$.

In a previous report (14) we described the generation of YAC transgenic mice with YRT2 DNA isolated by the method presented above. Mice from four out of the five transgenic lines analysed contained integrated copies of both vector arms, suggesting that the YAC DNA had remained intact during microinjection (Table I). Transfer of a $230 \mathrm{~kb}$ YAC by microinjection has been achieved in somatic cells: complete copies of the YAC DNA were integrated in 7 out of 10 clones (12). In contrast, a $590 \mathrm{~kb}$ construct was not transferred intact. It was speculated that the microinjection needle might impose a size limit on the passage of the YAC DNA. Polyamines were not included in that experiment (12), since they were shown to be dispensible for maintaining the integrity of the YAC DNA in solutions of high ionic strength $(100 \mathrm{mM} \mathrm{NaCl})$. Polyamines precipitate DNA in buffers of low ionic strength as a result of intra- and intermolecular bridges between the positively charged polyamines and the negatively charged DNA $(32,33)$. Electronmicroscopy studies show that globular structures form upon polyamine treatment of DNA (33). If it were possible to adjust the ionic strength and polyamine concentration to allow formation of compact globular structures without precipitation of DNA, microinjection of molecules well in excess of $250 \mathrm{~kb}$ could be possible. At the moment, we do not know whether our buffer conditions fulfill this requirement. Further microinjection experiments as well as electromicroscopic investigations of DNA in various buffers will show whether it is feasible to microinject larger YAC constructs. Because tyrosinase expression is such an easy phenotypic marker, our tyosinase YACs, the largest of which is $850 \mathrm{~kb}$, provide an ideal resource with which to pursue these experiments.

\section{ACKNOWLEDGEMENTS}

We should like to thank W.Fleischer for photography and C.Schneider for secretarial assistance. This work was supported by the Deutsche Forschungsgemeinschaft through SFB 229 and the Leibniz Programm, the Fonds der Chenischen Industrie, and the Imperial Cancer Research Fund.

\section{REFERENCES}

1. Burke, D.T., Carle, F.G. and Olson, M.V. (1987) Science, 236, 806-812

2. Pavan, W.J., Hieter, P. and Reeves, R.H. (1990) Mol. Cell. Biol., 10, 4163-4169.

3. Huxley, C., Hagino, Y., Schlessinger, D. and Olson, M.V. (1991) Genomics, 9, 742-750.

4. Pachnis, V., Pevny, L., Rothstein, R. and Constantini, F. (1990) Proc. Natl. Acad. Sci. U.S.A., 87, 5109-5113.

5. Jakobovits, A., Moore, A.L., Green, L.L., Vergara, G.J., Maynard-Currie, C.E., Austin, H.A. and Klapholz, S. (1993) Nature, 362, 255-258.

6. Gnirke, A., Bames, T.S., Patterson, W., Schild, D., Featherstone, T. and Olson, M.V. (1991) EMBO J., 10, 1629-1634.

7. Eliceiri, B., Labella, T., Hagino, Y., Srivastava, A., Schlessinger, D., Pilia, G., Palmieri, G. and D'Urso, M. (1991) Proc. Natl. Acad. Sci. U.S.A., 88, $2179-2183$.

8. Fernandez-Luna, J.L., Matthews, R.J., Brownstein, B.H., Schreiber, R.D. and Matthew, L.T. (1991) Genomics, 10, 756-764.

9. Strauss, W.M. and Jaenisch, R. (1992) EMBO J., 11, 417-422.

10. Choi, T.K., Hollenbach, P.W., Pearson, B.E., Ueda, R.M., Weddell, G.N., Kurahara, C.G., Woodhouse, C.S., Kay, R.M. and Loring, J.F. (1993) Nature Genetics, 4, 117-123.

11. Strauss, W.M., Dausman, J., Beard, C., Johnson, C., Lawrence, J.B. and Jaenisch, R. (1993) Science, 259, 1904-1907.

12. Gnirke, A., Huxley, C., Peterson, K. and Olson, M.V. (1993) Genomics, $15,659-667$

13. Schedl, A., Beermann, F., Thies, E., Montoliu, L., Kelsey, G. and Schütz, G. (1992) Nucleic Acids Res., 20, 3073-3077.

14. Schedl, A., Montoliu, L., Kelsey, G. and Schütz, G. (1993). Nature, 362, 258-261.

15. Smith, D.R., Smyth, A.P. and Moir, D.T. (1990) Proc. Natl. Acad. Sci. U.S.A., 87, 8242-8246.

16. Hill, A. and Bloom, K. (1987) Molec. Cell. Biol., 7, 2397-2405.

17. Ruppert, S., Müller, G., Kwon., B. and Schütz, G. (1988) EMBO J., 7, $2715-2772$.

18. Larin, Z., Monaco, A.P. and Lehrach, H. (1991) Proc. Natl. Acad. Sci. U.S.A., 88, 4123-4127.

19. Kelsey, G., Schedl, A., Ruppert, S., Niswander, L., Magnuson, T., Klebig, M.L., Rinchik, E.M., and Schütz, G. (1992) Genomics, 14, 275-287.

20. Anand, R., Villasante, A. and Tyler-Smith, C. (1989) Nucleic Acids Res., 17, 3425-3433.

21. Burgers, P.M.J. and Percival, K.J. (1987) Anal. Biochem., 163, 391-397.

22. Rose, M.D., Winston, F., and Hieter, P. (1990) 'Methods in yeast genetics: A laboratory course manual'. Cold Spring Harbor Laboratory, Cold Spring Harbor, NY.

23. Hogan, B., Constantini, F. and Lacy, E. (1986). Manipulating the Mouse Embryo, Cold Spring Harbor Laboratory Press, NY.

24. Beermann, F., Ruppert, S., Hummler, E., Bosch, F.X., Müller, G., Rüther, U. and Schütz, G. (1990) EMBO J., 9, 2819-2826.

25. Tanaka, S., Yamamoto, H., Takeuchi, S. and Takeuchi, T. (1990) Development, 108, 223-227.

26. Yokoyama, T., Silversides, D.W., Waymire, K.G., Kwon, B.S., Takeuchi, T., Overbeek, P.A. (1990) Nucleic Acids Res., 18, 7293-7298.

27. Rinchik, E.M. and Russell, L.B. (1990) In Genome Analysis, Vol.1, Davies, K. and Tilghman, S., eds, Cold Spring Harbor Laboratory Press, New York, pp. $121-158$

28. Holdener-Kenny, B., Sharan, S.K. and Magnuson, T. (1992) Bioessays, 14, $831-839$

29. Smith, D.R., Smyth, A.P., Strauss, W.M. and Moir, D.T. (1993) Mamm. Genome, 4, 141-147.

30. Couto, L.V., Spangler, E.A. and Rubin, E.M. (1989) Nucleic Acids Res., 17,8010 .

31. Brinster, R.L., Chen, H.Y., Trumbauer, M.E., Yagle, M.K. and Palmiter, R.D. (1985) Proc. Natl. Acad. Sci. U.S.A., 82, 4438-4442.

32. Gosule, L.C. and Schellman, J.A. (1978) J.Mol. Biol., 121, 311-326.

33. Chattoraj, D.L., Gosule, L.C. and Schellman, J.A. (1978) J.Mol.Biol., 121, $327-337$

34. Schedl, A. (1992). Ph.D. Thesis, University of Heidelberg, Germany. 